\title{
Evaluating the effects of redesigning a problem-based learning environment
}

Citation for published version (APA):

Segers, M. S. R., van den Bossche, P. G. C., \& Teunissen, E. (2003). Evaluating the effects of redesigning a problem-based learning environment. Studies in Educational Evaluation, 29(4), 315-334. https://doi.org/10.1016/S0191-491X(03)90016-2

Document status and date:

Published: 01/01/2003

DOI:

10.1016/S0191-491X(03)90016-2

Document Version:

Publisher's PDF, also known as Version of record

\section{Please check the document version of this publication:}

- A submitted manuscript is the version of the article upon submission and before peer-review. There can be important differences between the submitted version and the official published version of record.

People interested in the research are advised to contact the author for the final version of the publication, or visit the DOI to the publisher's website.

- The final author version and the galley proof are versions of the publication after peer review.

- The final published version features the final layout of the paper including the volume, issue and page numbers.

Link to publication

\footnotetext{
General rights rights.

- You may freely distribute the URL identifying the publication in the public portal. please follow below link for the End User Agreement:

www.umlib.nl/taverne-license

Take down policy

If you believe that this document breaches copyright please contact us at:

repository@maastrichtuniversity.nl

providing details and we will investigate your claim.
}

Copyright and moral rights for the publications made accessible in the public portal are retained by the authors and/or other copyright owners and it is a condition of accessing publications that users recognise and abide by the legal requirements associated with these

- Users may download and print one copy of any publication from the public portal for the purpose of private study or research.

- You may not further distribute the material or use it for any profit-making activity or commercial gain

If the publication is distributed under the terms of Article $25 \mathrm{fa}$ of the Dutch Copyright Act, indicated by the "Taverne" license above, 


\title{
EVALUATING THE EFFECTS OF REDESIGNING A PROBLEM-BASED LEARNING ENVIRONMENT
}

\author{
Mien Segers, Piet Van den Bossche and Emily Teunissen \\ Faculty of Economics and Business Administration, Department of Educational Development and Research, \\ University of Maastricht, the Netherlands
}

Introduction

Though learner-centered and constructivist, there is broad agreement that ProblemBased Learning (PBL) environments are effective in various aspects. Self-dependent learning skills and a well-structured knowledge base are mentioned as two benefits of PBL, with self-dependent learning defined as a tool as well as a goal (Barrows \& Tamblyn, 1980; Blumberg \& Michael 1992; Dolmans \& Schmidt, 1994, 1996; Norman \& Schmidt, 1992; Vernon \& Blake, 1993). However, various research studies indicate problems within PBL practice. One of the issues of most concern is the learning paradox noted by Schanck and Cleave (1995, p. 178): "how can students learn by doing what they do, when they do not know how to do what they have to learn?" Vermunt and Verloop (1999) argue that the degree of self-dependent learning is not always developed at optimum level in the PBL practice. Effective educational systems should gradually offer more control over the process of learning by students. They should scaffold for self-dependent learning. Authors like Williams (1992), Kinzie (1990), and Savery and Duffy (1995) have expressed similar ideas. Thomas (2000) states that the effectiveness of PBL as an instructional method probably depends to a great extent on the incorporation of a range of supports to help 
students learn how to learn. However, to date, only few research studies focus on the evaluation of the effects of design variables aimed to support learning in PBL.

In view of the gap in empirical literature, the major aim of this arlicle is to present the results of an initial evaluation of a redesigned PBL course, intending to enhance students' learning by scaffolding students in the development of self-dependent learning skills. According to the evaluation model of Pepper and Hare (1999), we will evaluate the redesigned course taking into account two different components of the evaluation model: the transaction component and the outcomes component. We first will describe the goals or intents of the redesign. Second, we will present the data concerning the actual implementation of the program (the transaction component) as perceived by the students. Third, the students' outcomes will be presented.

\section{Problem Based Learning and Self-Dependent Learning}

PBL, as initially developed by Barrows and Tamblyn (1980), typically involves students working on problems in small groups of five to twelve, with the assistance of a faculty tutor. Problems serve as a starting point for new learning activities. The analysis of these problems results in the acquisition of knowledge and of problem-solving skills. Problems are encountered before all relevant knowledge has been acquired, rather than after reading texts or attending lectures about the subject matter underlying the problems. This feature reflects one of the essential distinctions between PBL and other problemoriented methods (Albanese \& Mitchell, 1993). The teacher, called the tutor, coaches the group by monitoring the group process and helping the students to identify the knowledge that is necded to resolve the problem. The lcarning process is structured according to the seven-jump method. This means that the process starts with a preliminary analysis of the problem, based on the students' prior knowledge (the problem analysis phase). It results in the formulation of the students' learning goals or of the unexplained issues that students need to investigate during self-study before follow-up meeting(s). After completing the problem-solving cycle, students will start to analyze a new problem, again following the described problem solving procedure (e.g., Williams, 1992).

1. Understand all terms

2. Define the problem

3. Analyse the problem (Brainstorm: activate prior knowledge, discuss)

4. Synthesize (Arrange ideas)

5. Define learning objectives

6. Self-study

7. Report back

1-5: pre-discussion, 7: post-discussion

Figure 1: The Seven-Jump Procedure in PBL 
In PBL, the seven-jump method as well as the coaching by the tutor are two design variables aiming to foster self-dependent learning. However, in PBL, self-dependent learning is a tool as well as a goal. It is learning by doing. Becoming self-dependent experts by working as self-dependent learners on problems is the core approach in PBL. First of all, the seven-jump method structures the students' learning process into seven steps to take in order to tackle the problem. As an inherent aspect of this problem-solving process, the students are stimulated to formulate their own learning goals and to reflect on the quality of their learning, the process as well as the outcomes. Second, the tutor has a supporting role: he coaches the learning process in the group.

Over the past few years, empirical research has been conducted to measure the effectiveness of PBL. Implementation research studies intend to describe, explore and investigate the process of planning and enactment of PBL. It includes research focusing on design variables of PBL. The findings of some of these studies will be discussed in the next section.

\section{Effectiveness of PBL and its Relationship with Self-Dependent Learning}

In discussions about the effectiveness of the PBL system, control in PBL environments is gaining more attention (e.g., Albanese, 2000; Vermunt \& Verschaffel, 2000). Cognitive researchers have argued that a certain degree of learner control is an essential aspect of effective learning environments (Kinzie, 1990; Vermunt \& Verschaffel, 2000; Williams, 1992). The claimed effects of a higher degree of student control (instead of teacher/program control) are intrinsically highly motivated students and more active and autonomous students. In this respect, different concepts are used to refer to students' control over their own learning: self-directed learning, independent learning, selfdependent learning. In this article, we will use these concepts as synonyms.

Offering more student control is related to the degree of scaffolding (Greening, 1998) and can be expressed by more freedom in the choice of problems, learning-goals, literature and by working more independently from a tutor (Vermunt \& Verschaffel, 2000). Savery and Duffy (1995) argued that with authentic problem tasks, a learner should have ownership over the process of problem solving, the problem itself and the learning goals. When students are able to work independently, less scaffolding can be provided. It is essential that optimal levels of challenge (and motivation) in a learning setting be maintained (Greening, 1998).

A few evaluative research studies focus on design variables in PBL environments. They focus on challenges encountered by students and, in that respect, refer to problems on the control or support dimension of a PBL environment.

The research of De Grave, Boshuizen, and Schmidt (1996) indicated that in several PBL curricula the brainstorming phase is poor and/or short, resulting in one single problem explanation. The fact that explanations are often not provided, or compared, leads to a rather poor or superficial problem analysis, with few elaborations (De Grave, 1998). De Grave concludes that, additionally, deriving a hypothesis at a too early stage can result in prejudices or misconceptions (Barrows \& Tamblyn, 1980). These findings are similar to the results of a study by Houlden, Collier, Frid, John, and Pross (2001) who described typical behavior of students in PBL-curricula in terms of their rapidly focusing on the 
solution or "right answer". The emphasis in PBL is, however, not necessarily on solving the problem, but rather on analyzing and explaining the possible causes and characteristics of a phenomenon (Hmelo \& Evensen, 2000), and the underlying principles. Salomon and Perkins (1989) state that such learning requires that explicit attention be paid to abstracting knowledge, making generalizations from the problem and reflecting on the problem solving process to understand when the learned knowledge can be applied. One of the underlying reasons for the problems indicated in the PBL practice is that first-year students are not experienced with PBL. This leads to the question to what extent students need support in first understanding the relevance and meaning of the expected learning activities.

Krajcik, Blumenfeld, Marx, Bass, Fredricks, and Soloway (1998) refer to similar problems, described as inquiry problems. Krajcik et al. (1998) present case studies of eight students enrolled in two seventh-grade science classrooms. The students were selected from the classroom population as representative of the lower-middle range of science achievement and on the basis of the likelihood that they would be informative interviewees. Classrooms were videotaped and the students were interviewed frequently. The results were described with respect to aspects of the inquiry process that students handled adequately and those with which students had difficulty. Students showed proficiency at generating plans and carrying out procedures. However, students had difficulties with: (1) generating meaningful scientific questions; (2) managing complexity and time; (3) transforming data, and (4) developing a logical argument to support claims. The researchers claim that the findings point to the need for developing multiple supports for students as they conduct their inquiry.

Besides problems students face, Marx, Blumenfeld, Krajcik, and Soloway (1997) describe the enactment problems of teachers in PBL. Beside problems concerning time and classroom management, control, technology use and assessment, the Michigan University research team refers to the problem of supporting students' learning. Teachers have difficulty scaffolding students' activities, sometimes giving them too much independence or too little modeling and feedback.

On the basis of a review of intervention studies intending to evaluate and improve the effectiveness of PBL, Thomas (2000) presents a range of interventions aimed to support students in PBL. Thomas (2000) describes the underlying deficiencies of students when performing the various activities in PBL and suggests interventions. These inquiry problems and suggestions for intervention are schematized in Figure 2.

The underlying deficiencies Thomas describes all refer to the students' self-directed learning skills. Students need a repertoire of learning strategies in order to be able to engage in independent learning. Effective educational systems provide mature (graduate) students with a higher degree of control than is given to novice students. According to McLoughlin and Hollingworth (2001), effective teaching of problem-solving requires the adoption of process-based approaches that reveal to students the ways that experts solve problems, and the coaching of students in higher-order cognitive and metacognitive skills. They refer to a study of Taconis, Ferguson-Hessler, and Broekkamp (2001) who have recently analysed studies (published in international journals between 1985 and 1995) on the effectiveness of teaching strategies for science problem-solving: 
In short, the results indicate that in student performance, providing strategy training and practice in problem-solving turned out to be not effective, whereas effective teaching of problem-solving gives attention to contextualised strategies related to domain knowledge. (Taconis et al., 2001, p. 117)

An effective instructional approach should include the provision of support for learning problem-solving processes (Jonassen, 1997).

\begin{tabular}{|c|c|}
\hline Context & Underlying deficiency \\
\hline $\begin{array}{ll}\text { 1. } & \text { Beginning inquiry } \\
\text { - } & \text { Asking questions } \\
\text { - } & \text { Formulating goals } \\
\text { - Planning procedures }\end{array}$ & $\begin{array}{l}\text { Students have difficulty generating } \\
\text { the essential questions that will lead } \\
\text { them to encounter and understand the } \\
\text { central concepts of a subject matter } \\
\text { area. }\end{array}$ \\
\hline & $\begin{array}{l}\text { Students have difficulty, in general, } \\
\text { framing questions to guide their } \\
\text { inquiry and, in particular, developing } \\
\text { questions that have scientific merit. }\end{array}$ \\
\hline
\end{tabular}

Intervention
Prompting "Learning Appropriate
Goals" by introducing specifications,
asking for plans, helping students to
develop "driving questions".

The use of steps to guide beginning inquiry, with peer or teacher feedback
2. Directing inquiry

- Conducting information/data collection

- Conducting knowledge searches

- Constructing knowledge
Students have difficulty with openended situations and with ill-defined problems.

\author{
Providing students with practice in \\ conducting (packaged) problem- \\ based learning activities.
}

Providing a structured set of inquiry steps for students to follow.
3. Conducting an inquiry

Students have difficulty with the
process of inquiry. They elect to
follow dubious, unproductive paths;
they have trouble interpreting the
meaning of newly found information;
they don't always focus on end goals.
Students have difficulty knowing
when they comprehend fully.
Students have difficulty recognizing
gaps in knowledge and knowing
where they are in knowledge
acquisition activities.

\author{
Providing an embedded coaching \\ process that depends on and \\ preserves student initiative, yet \\ allows for teacher interpretation and \\ teacher-student negotiation: \\ "Transformative communication".
}

4. Acquiring and presenting Knowledge

- Knowing when you understand

- Knowing what it means to be an expert

- Monitoring what is known

- Demonstrating the full range of one's competence

\author{
Intervening to require explanations \\ and justifications from students at \\ different stages of the problem \\ solving process. Making knowledge \\ building overt, public and collective. \\ Emphasizing learning vs. work \\ completion and understanding vs. \\ product quality goals for student \\ work.
}

Figure 2: Inquiry Problems in PBL (adapted from Thomas, 2000)

A concrete example of providing student support in a PBL environment is described by Arts, Gijselaers and Segers (2002). They conducted a study to measure the cognitive effects of a redesigned PBL environment. The PBL environment was redesigned 
on the task, control and social dimensions. Starting from the seven-jump procedure, the guidance and scaffolding of the learning process was optimized by various design variables. Students brainstormed within small self-steering sub teams, guided by a form explicating the various steps in the problem-analysis process they had to take. The tutor gave feedback to the sub-teams and brought together the revised products (forms) of the sub-teams. Second, as a result of the self-study, students were required not only to work on the learning goals but also to prepare discussion points for the post-discussion. One of the aims of the redesign was to adapt students' guidance and scaffolding to their experiences with PBL. The results of this quasi-experimental study indicated that this redesigned PBL environment enhanced students' cognitive learning outcomes as measured by the end-ofcourse test. Using the think-aloud research method in order to unravel these cognitive outcomes, the students from the redesigned learning environment outperformed the regular PBL students in various cognitive processes. The analyses of student performances on the case study indicated that the intervention (a redesigned PBL format) resulted in both more use of formal discipline and "practical" knowledge, when compared with the regular PBL setting. The experimental students demonstrated superior reasoning behavior in three aspects: (a) inductive reasoning behavior; (b) diagnostic quality, and (c) quality of case problems provided. The results of this study and the experiences with the design of this (redesigned) learning environment were the starting points for the intervention study described in this article.

\section{A PBL Environment Supporting Self-Dependent Learning of First Year Students}

The gencral goal of redesigning the PBL-course was to optimize students' learning in terms of the actual implementation of PBL, as perceived by the students, as well as in terms of the student outcomes. Observations in regular PBL tutorial groups of first-year students indicated three main problems: (1) mediocre activity of students in and outside the tutorial group; (2) poor quality of the pre- and post-discussion, and (3) a loosely structured knowledge base as a cognitive outcome of the learning process. Analyzing these observations has led to the question to what extent students as well as, often inexperienced, tutors are caught in the dilemma of "learning-by-doing". Observations indicated that firstyear students only to a minor extent possess the necessary skills to work as self-dependent learners in the PBL-environment. Only few of them are able to operationalize the learning activities of the seven-jump procedure. These observations as well as the results of previous PBL research were the starting point for redesigning the PBL environment.

The goal of the redesign is to optimize support of first-year students' problemsolving process in order to reach a higher effectiveness in terms of cognitive outcomes and more positive perceptions of the qualities of the learning environment.

A PBL course focusing on macro-economics, at the University of Maastricht's School of Economics and Business Administration, was selected as the experimental setting for feasibility reasons on the one hand, and for the highly analytical and conceptual level of this course, on the other. It was the third course (module) in the first year, after two courses on management and organization and on micro-economics, both in PBL format.

Based on the findings of research on the effectiveness of PBL as presented in the previous section and based on the positive experiences of the Arts et al. study (2002), the 
PBL course was redesigned with reference to a number of aspects. In short, when comparing the experimental PBL course with the control (regular) PBL course, the main difference is the explication of the various learning activities students are supposed to perform when using the seven-jump method. The tutor coaches explicitly, clarifies the expected learning activities and gives feedback on the quality of the performed activities. By stimulating students to work in small sub-teams when working on the learning goals during the self-study period, the effects of cooperative learning are optimized.

In the experimental PBL course, the learning process, following the seven-jump procedure, was unraveled in a set of learning activities students were expected to perform in order to acquire the main concepts, models and theories in the field under study. To support students and tutors, the Optima Card was developed, presenting the expected learning activities for each of the steps in the seven-jump procedure (see Figure 3).

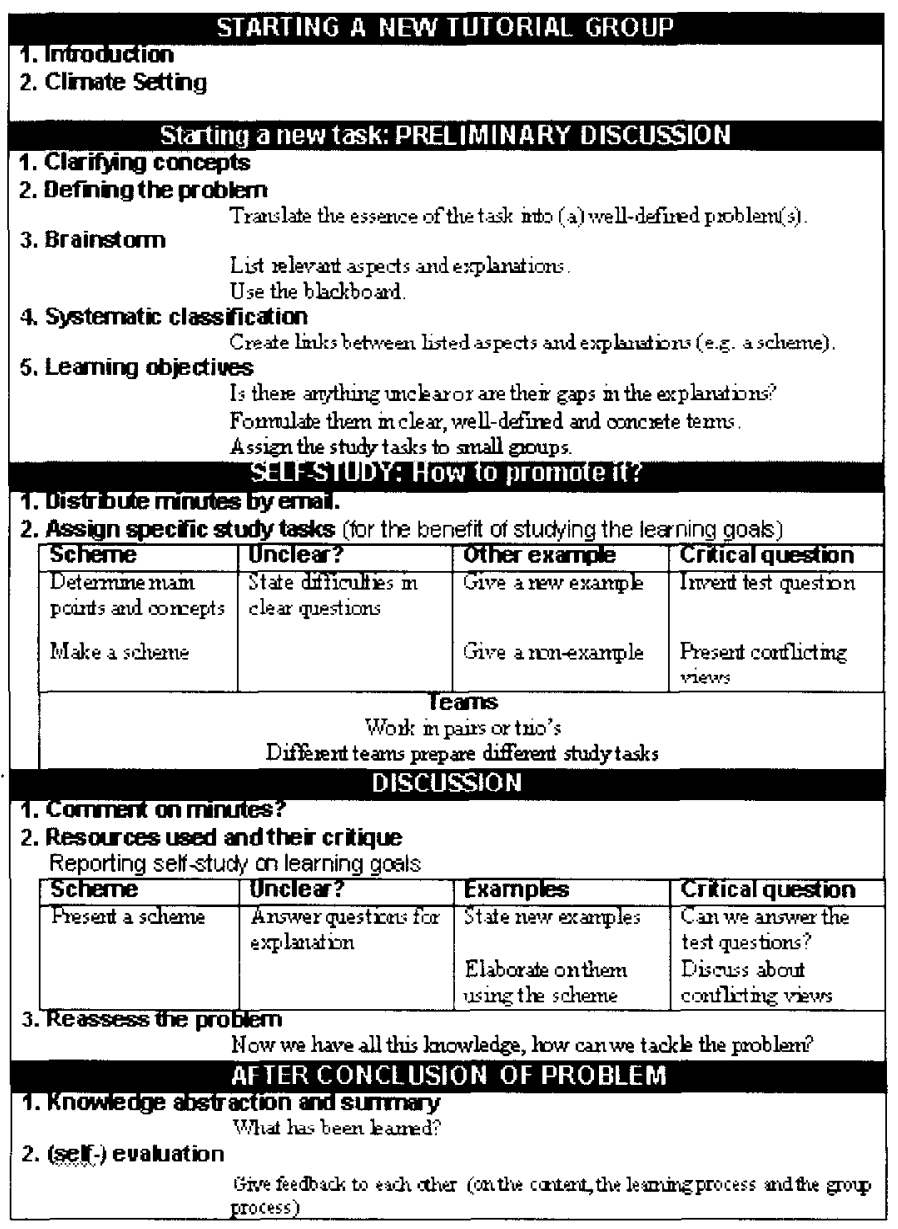

Figure 3: The Optima Card 
Students as well as tutors used the Optima Card as a personal guide through the course. Each student and each tutor had his/her own personal card.

For the pre-discussion, the seven jump traditionally includes five steps: clarifying concepts, defining the problem, analyzing the problem, synthesizing the ideas and formulating learning goals. For the redesigned PBL course, the five steps of the sevenjump procedure are formulated in a set of activities students are expected to perform.

In the pre-discussion, the tutor plays an important role as coach. During the selfstudy period, the second phase in the seven-jump procedure (step six in the regular seven jump procedure), the tutor is not coaching the process. The only guidance is offered by the outcomes of the pre-discussion: an initial analysis of the problem and a set of learning goals. In order to offer the students support by clarifying the activities enabling them to acquire these learning objectives, in the redesigned PBL course, a set of activities are proposed. The main activity for acquisition of learning goals is information processing. A set of cognitive processes underlies this information processing: (1) selecting relevant information, (2) relating and structuring the bits of information; (3) concretizing and applying this information in the context of the initial problem and learning objectives; (4) analyzing critically the information gathered, and (5) evaluating critically the information processing. These cognitive processes were translated into a set of learning activities: (1) identify main points and concepts in the information resources; (2) make a scheme of the main points and concepts; (3) give new concrete examples of problems and non-problems for which the theoretical model (concept, theory, structure) is relevant; (4) identify what points, aspects of the problem and/or theoretical framework are still unclear to you, and (5) evaluate your own understanding and that of your peers by asking critical questions and/or presenting conflicting views.

In order to support each other in performing the learning activities, the students were stimulated to work in pairs or trios. The five activities presented and the underlying cognitive processes are the core business of the post-discussion. According to the agreements made at the end of the pre-discussion, small teams of students presented their results of the self-study as a starting point for discussion in the tutorial group. The postdiscussion ends with the re-assessment of the problem: How can we tackle the problem with the theoretical framework(s) we acquired?

In PBL environments using the regular seven-jump procedure, the learning process ends here. In the redesigned course, in order to optimize the learning effects, i.e., cognitive (well-structured knowledge base) as well as metacognitive (self-dependent learning) effects, a feedback phase is introduced, guided by two questions: 1 . In sum, What did we learn? and 2. What is the quality of both the individual and group learning process?

\section{Research Method}

\section{Research Questions}

The present research investigates the effectiveness of the redesigned course by looking at different aspects of the course, including the processes or transactions and the cognitive outcomes (Pepper \& Hare, 1999). First, the actual implementation of the redesign is evaluated. For this purpose, student perceptions regarding various quality 
aspects of the course are assessed. This implies quality criteria such as the relevance of the course for the future, its contribution to students' knowledge base and the extent to which it stimulates students' interest. Besides, the students' perceptions of the quality of two important tools for learning in a PBL setting are measured: the tutorial group and the tutor.

The second goal of the study is to examine whether the experimental setting, when compared with a regular PBL environment, would yield different learning outcomes in terms of acquiring a well-structured knowledge base and the applicability and the transferability of the knowledge acquired. The research question is therefore: Does the new learning environment (when compared to a regular PBL situation) lead to (1) a better structured knowledge base and (2) a better application of knowledge in new and authentic problem solving situations?

\section{Participants}

First-year students from the Maastricht School of Economics and Business Administration participated in the present cxperiment. Of the 250 students who enrolled for the macro-economics course under study, 39 students participated in the experimental group, and 66 students participated in the control group. The students were randomly selected out of the total student course population and they were randomly assigned to the tutorial groups.

Initially, 105 students participated in the two conditions. However, as the experiment was carried out in an ecological context, natural attrition of students occurred. For instance, some students did not answer all questions in the survey or did not do both previous PBL tests used as proxy measures. This explains the variance in the number of participants in the tables presented.

\section{Design}

A quasi-experimental comparative design was set up, consisting of two randomized student groups: one experimental group and one control group (see Table 1). The experimental group consisted of four tutorial groups. In order to control for a tutor effect, the seven control groups were coached by the same four lutors.

Table 1: Design for the Evaluation of the Redesigned PBL Environment

\begin{tabular}{lccc}
\hline Group & $\begin{array}{c}\text { Pre-knowledge } \\
\text { analysis (GPA) }\end{array}$ & $\begin{array}{c}\text { Treatment: the } \\
\text { redesigned PBL }\end{array}$ & $\begin{array}{c}\text { Treatment test: } \\
\text { case study } \\
\text { MC questions }\end{array}$ \\
\hline $\begin{array}{l}\text { Experimental } \\
\text { PBL group }\end{array}$ & $\mathrm{O}_{0}$ & $\mathrm{X}$ & $\mathrm{O}_{1}$ \\
\hline Control group & $\mathrm{O}_{0}$ & $\mathrm{O}_{1}$ \\
\hline
\end{tabular}

First, in order to collect information for the transaction component, the PBL Course Experiences Questionnaire (Gijselaers, 1988) was used. It served to assess students' perceptions of the quality of various aspects of the course. Second, in order to measure the 
main effects of the redesign on the student outcomes, a multiple choice test as well as an authentic case study test was used as a post-test. It would not make sense to give a preexperimental test to students who have never studied a macro-economics course. Also, using a pre-test at the beginning of the experiment could influence the outcomes of the experiment (Cook \& Campbell, 1979). Therefore, we used an "untreated control group design with proxy pre-test measures". In such designs a post-test is the main measure of treatment, and proxy measures should be found that correlate with the post-test scores. An example of such a pre-test is a general aptitude test in the subject area that is being investigated. Statistical power increases if the scores of the proxy pre-test are related to the post-test (Cook \& Campbell, 1979). In the present study, as a proxy pre-test, students' GPAs (their performances on the two prior courses with a PBL-format) were used as a general measure of business aptitude. The correlation between the performances on the two prior courses and on the post-test turned out to be between .63 and .67 (Pearson, 2-tailed, significant at .01 level). This correlation is acceptable for using the GPA as proxy pretest measure.

\section{Tutors}

For the experimental condition, four tutorial student groups were set up. For the control conditions, seven tutorial groups were set up. Hence there were eleven tutorial groups in total. Tutors were crossed with both conditions to apply a control for any "tutor effect" during the course.

\section{Instruments}

For the experimental as well as the control group, students' perceptions of the learning environment were measured with the PBL-Course Experiences Questionnaire (Gijselaers, 1988). The questionnaire consists of 56 statements relating to four PBL design variables (1) the course book; (2) problem tasks; (3) the tutorial group, and (4) the tutor. A set of statements is related to the general impression of the block concerning motivation, organization and relevance of the subjects. The statements refer to the expected benefits of PBL.

To measure the outcomes component, for the two groups, two cognitive measures were used. First, the effects of the intervention were measured by open-ended questions related to a case study, which was novel to the students. The case study was a OECD report. The test was a problem-based test in the sense that students were confronted with a problem description based on the OECD data. The test part of the case study consisted of three large essay questions, each counting for a maximum of 15 credits. The block planning team constructed the questions. The instrument measured the cognitive outcomes in terms of knowledge application and transfer. An example of questions is presented in the Appendix. Individual answers to each item were checked against a standard scoring key. To enhance the reliability of scoring, each tutor rated one question for all students.

Second, a set of multiple choice (MC) questions measured the extent to which students possessed a well-organized knowledge base of the macro-economics themes 
discussed. The test consisted of $70 \mathrm{MC}$ questions. Two examples of questions are presented in Figure 4.

1. In macro-economics a distinction is made between models with flexible and with sticky prices.

True/?/false In models with flexible prices the price level is an endogenous variable.

2. Romeria is an economy with a so called "fractional reserve banking system". The Romerian roller is the official currency. The income velocity of money is constant. Output grows on average by $3 \%$ per year, and the inflation rate is $2 \%$ annually. The Romerian money supply consists of cash and checking deposits Because of the steady growth of the informal sector, the Romerians want to hold an ever-increasing part of their money balances in the form of cash.

True/?/false The monetary base of Romeria (B in Mankiw) increases by less than $5 \%$ a year.

Figure 4: Two Examples of MC Questions

Third, to provide a control for the probability that the experimental students had a higher level of prior knowledge than the control group students, a proxy measure was used which correlated with the post-test that was used with the treatment groups (Cook \& Campbell, 1979). As proxy measure, the GPA was estimated on the basis of the students' performances on the two courses with a PBL format that the students had followed prior to the experiment.

\section{Data Analysis}

To provide an answer to the research questions, mean differences between the study groups in terms of their perceptions of the course and of the achievements on the assessment instruments were compared by using $t$-tests for independent samples.

\section{Results 1: Students' Perceptions of the Learning Environment}

The results of the PBL Course Experiences Questionnaire indicate to what extent the students perceive the learning environment as of good quality. More than the control group students, the experimental students indicated it was possible to understand the subject matter in the course. Concerning the organization of the course, the experimental students were significantly more positive than the control group students.

The results indicate significant motivational effects of the intervention. The experimental students perceived the tutorial groups as more stimulating, pleasant and productive. The experimental students appreciated the tutor significantly more than the control group students in his role of encouraging participation in group discussions and in his role to stimulate the formulation of relevant learning goals. In general, the overall grade the tutors received from the students was significantly higher for the experimental groups 
than for the control groups. Additionally, in comparison with the control group students, students from the experimental groups indicated that their tutorial group meetings lasted longer. Finally, the experimental students gave a significantly higher overall grade to the block.

Table 2: Items of the PBL Course Experiences Questionnaire with Significant Differences Between Experimental and Control Group Students

\begin{tabular}{|c|c|c|c|c|}
\hline $\begin{array}{l}\text { Items from the PBL Course Experiences } \\
\text { questionnaire }\end{array}$ & group & $\bar{N}$ & $\begin{array}{l}\text { Mean score } \\
\text { point scale) }\end{array}$ & $(5-$ \\
\hline \multirow{2}{*}{$\begin{array}{l}\text { The subject matter in the course was difficult to } \\
\text { understand }\end{array}$} & $E$ & 32 & 2.8 & .7 \\
\hline & $\mathrm{C}$ & 50 & 3.2 & .8 \\
\hline \multirow[t]{2}{*}{ This course was well organized } & $\mathrm{E}$ & 32 & 4.1 & .6 \\
\hline & $\mathrm{C}$ & 50 & 3.7 & .8 \\
\hline \multirow{2}{*}{$\begin{array}{l}\text { The course book was well structured around the } \\
\text { general theme of this course }\end{array}$} & $\bar{E}$ & 32 & 3.9 & .8 \\
\hline & C & 50 & 3.4 & .8 \\
\hline \multirow{2}{*}{$\begin{array}{l}\text { In general, the tasks were too prescriptive as to what } \\
\text { one was expected }\end{array}$} & $\mathrm{E}$ & 32 & 3,3 & .8 \\
\hline & $\mathrm{C}$ & 50 & 2.7 & .9 \\
\hline \multirow{2}{*}{$\begin{array}{l}\text { I found the meetings of the tutorial group } \\
\text { stimulating }\end{array}$} & $\mathrm{E}$ & 32 & 4.4 & .6 \\
\hline & $\mathrm{C}$ & 50 & 3.7 & .9 \\
\hline \multirow{2}{*}{$\begin{array}{l}\text { I found it a pleasure to work in this discussion } \\
\text { group }\end{array}$} & $\mathrm{E}$ & 32 & 4.3 & .9 \\
\hline & C & 50 & 3.9 & .9 \\
\hline \multirow[t]{2}{*}{ The meetings turned out to be productive } & $\bar{E}$ & 32 & 4.3 & .7 \\
\hline & $\mathrm{C}$ & 50 & 3.7 & .9 \\
\hline \multirow{2}{*}{$\begin{array}{l}\text { The tutor encouraged a thorough analysis of new } \\
\text { problems }\end{array}$} & E & 32 & 4.4 & .7 \\
\hline & C & 59 & 4.1 & .6 \\
\hline \multirow{2}{*}{$\begin{array}{l}\text { The tutor encouraged the formulation of relevant } \\
\text { learning goals }\end{array}$} & E & 32 & 4.3 & .7 \\
\hline & $\mathrm{C}$ & 50 & 4.0 & .7 \\
\hline \multirow{2}{*}{$\begin{array}{l}\text { Evaluate the overall functioning of this tutor with a } \\
\text { grade on a ten-point scale }\end{array}$} & $\mathrm{E}$ & 32 & 8.9 & .9 \\
\hline & $C$ & 50 & 8.1 & .8 \\
\hline \multirow{2}{*}{$\begin{array}{l}\text { Please provide an overall grade for the block on a } \\
\text { ten-point scale }\end{array}$} & $E$ & 30 & 7.7 & .8 \\
\hline & C & 50 & 7.0 & 1.0 \\
\hline \multirow{2}{*}{$\begin{array}{l}\text { How long (on average) did the tutorial group meet } \\
\text { (less than } 1 \text { hour, between } 1 \text { and } 13 / 4 \text { hour, between } \\
13 / 4 \text { hour and } 21 / 4 \text { hour, } 21 / 4 \text { hours and more) }\end{array}$} & $E$ & 32 & 3.0 & .4 \\
\hline & $\mathrm{C}$ & 48 & 2.5 & .5 \\
\hline
\end{tabular}




\section{Results 2: Students' Cognitive Outcomes}

Table 2 shows the mean scores of the three student groups for the essay questions in the case study test and for the MC questions (results are collapsed over the four tutors).

Table 3: Mean Student Scores for the Case Study Test and the MC Test

\begin{tabular}{lccccc}
\hline Group & & Score for case study test & \multicolumn{2}{c}{ Score for MC test } \\
\hline & $N$ & $\begin{array}{c}\text { Mean score } \\
(\mathrm{Max}=30)\end{array}$ & $S d$ & $\begin{array}{c}\text { Mean score } \\
(\mathrm{Max}=60)\end{array}$ & $S d$ \\
\hline $\begin{array}{l}\text { Experimental } \\
\text { group }\end{array}$ & 39 & 17.6 & 8.2 & 36.8 & 17.2 \\
\hline \begin{tabular}{l} 
Control group \\
\hline
\end{tabular} & 66 & 19.5 & 6.9 & 30.6 & 15.6 \\
\hline
\end{tabular}

A $t$-test was performed. The mean scores of the two conditions revealed no significant differences between the means of the two groups for the essay questions $[t(103)=1.275, p$ $=.205]$ as well as for the MC questions $[t(103)=-1.887, p=.062)$.

In order to measure the influence of the students' language on their performances on the tests, a univariate analysis of variance was performed. The results showed no significant differences in total test score (case study test and $\mathrm{MC}$ test) $[F(1,77)=.090, p=.764]$ between the English $(n-=39)$ and Dutch speaking students $(n=40)$.

In order to measure the influence of the tutorial group $(n=11)$ students were assigned to and the influence of the tutor $(n=4)$, a univariate analysis of variance was performed. It revealed no significant differences between the tutorial groups $[F(10,92)=$ $.247, p=.995]$ nor between the tutors $[F(3,101)=.207, p=.891]$ nor an interaction effect between conditions and tutors $[F(5,97)=.210, p=.889]$.

\section{Results 3: Control Study}

The control test was designed to assess whether, at the start of the experiment, the two groups in the experiment were equal with regard to prior knowledge. The GPA of the students was expressed by the average scores of the students in the two groups on the two PBL tests they had already done.

The findings of a MANOVA indicate that the two groups did not differ in knowledge acquired from the first PBL course they had followed prior to the start of the experiment $[F(1,100)=.126 ; p=.724]$ and from the second PBL course $[F(1,100)=1.385$; $\mathrm{p}=.242]$. This suggests that, at the start of the experiment, the two student groups were equal with regard to relevant prior knowledge scores.

\section{Discussion and Conclusion}

Evaluative research on the effectiveness of programs or courses with a PBL instructional approach does not present conclusive results. Thomas (2003) states that the 
effectiveness of PBL as an instructional method probably depends to a great extent on the incorporation of a range of supports to help students learn how to learn. Therefore, in the study presented, a PBL course was redesigned, taking into account the results of research on the effects of several design variables in PBL programs. The purpose of the redesign was to enhance students' learning processes and increase their learning outcomes by supporting them in the development of self-dependent learning outcomes. The research study aimed to evaluate two components of the redesigned course: the transaction and the outcomes component. The results of the PBL course experiences questionnaire, measuring the students' perceptions of the quality of the actual learning environment, indicate significant differences between the perceptions of the control group and the experimental group. Overall, the experimental students, who received additional support, appreciated the course more, indicating the productivity of the tutorial meetings and the stimulating role of the tutor for the quality of problem-solving process.

Besides evaluating the transaction component, we explored whether the redesigned course, when compared with a regular PBL course, would lead to an increased effectiveness in terms of student achievement. In the present experiment, scores on the MC test as well as on a case study test were analyzed for evaluating the outcomes component. This analysis showed that the students who experienced the redesigned PBL format did not have significantly better scores compared to the control group. In general, it can be concluded that the redesigned PBL format did not contribute significantly to student learning outcomes when compared with the regular PBL setting. This result cannot be explained by differences in prior knowledge. The control test on student selection showed no significant differences between the experimental and control students at the start of the experiment. We further explored the data, comparing mean test scores by students' language, the tutorial group in which they participated, the tutor and the interaction between tutor and condition. These results were negative.

An issue to consider is the validity of the instrument used for measuring cognitive outcomes. The question is to what extent do MC test and case study match the cognitive processes supported and realized in the tutorial group. There are indications for a lack of alignment between the students' and teachers' perceptions of the assessed cognitive processes and the cognitive processes taking place in the tutorial groups as perceived by the students and the tutors (Segers, 2003).

Besides, the current operationalization of the construct of cognitive outcomes can be questioned. The evaluation focused on the students' individual cognitive learning outcomes. Salomon (1996) argued that implementing new constructivist learning environments should also be accompanied by the assessment of new cognitive learning goals. For example, in designing a learning environment that assumes different group knowledge construction processes, one should also investigate process outcomes related to aspects such as shared understandings, as well as doing cognitive tests. Future evaluations of constructivist learning environments should reconsider the nature of the cognitive processes aimed for, at the individual as well as at the group level.

In addition to cognitive outcomes, future evaluations should also address metacognitive outcomes. For future learning, meta-cognitive outcomes such as self-dependent learning skills are of great importance (Bransford \& Schwartz, 1999). Although the students in the redesigned course did not outperform the control group students on the 
cognitive outcomes measures, it might be that students in experimental setting did acquire skills for more effective self-dependent future learning. Additionally, it is well known from former studies within the CSCL research domain that, besides cognitive achievement, affective or motivational changes may occur, along with changes in interaction. The data of the PBL Course Experiences Questionnaire indicate that motivational changes indeed occurred.

Another issue, related to "future learning", concerns the short-term effects measured in this study. As is known from earlier research, educational innovations such as PBL often do not lead to cognitive gains in the short term, but do so in the long term (Norman \& Schmidt, 2000). Further evaluative research should take a long-term perspective, indicating to what extent the redesigned course has long term effects.

A general implication of the results of this study for educators is that evaluation of educational innovations asks for a multidimensional approach. Educational change is complex, affecting students and teachers on various dimensions. A comprehensive evaluation model as developed by Stake (1967) and adapted by Pepper and Hare (1999) is an important tool to unravel this effect. A further analysis of the various components of the model in the context of the specific educational innovation might contribute to a better understanding of the multiple effects of this innovation.

\section{References}

Albanese, M. (2000). Problem-based learning: Why curricula are likely to show little effect on knowledge and clinical skills. Medical Education, 34 (9), 729-738.

Albanese, M., \& Mitchell, S. (1993). Problem-based learning: A review of the literature on its outcomes and implementation issues. Academic Medicine, 68, 1,52-81.

Arts, J., Gijselaers, W., \& Segers, M. (2002). Cognitive effects of an authentic computer-supported, problem-based learning environment. Instructional Science, 30, 465-495.

Barrows, H., \& Tamblyn, R. (1980). Problem-based learning: An approach to medical education. New York: Springer.

Blumberg, P., \& Michael, J. (1992). Development of self-directed learning behaviours in a partially teacher-directcd problem-based learning curriculum. Teaching and Learning in Medicine, 4, 3-8.

Bransford, J.S., \& Schwartz, D.L. (1999). Rethinking transfer: A simple proposal with multiple implications. Review of Educational Research, 24, 61-100.

Cook, T.D., \& Campbell, D.T. (1979). Quasi-experimentation: Design and analysis for field settings. Chicago, Illinois: Rand McNally.

De Grave, W.S. (1998). Probleemgestuurd leren als kennisconstructie [Problem based learning as knowledge construction]. Unpublished doctoral dissertation, University of Maastricht. Maastricht: Universitaire Pers Maastricht.

De Grave, W.S., Boshuizen, H.P.A., \& Schmidt, H.G. (1996). Problem based learning: Cognitive and metacognitive processes during problem analysis. Instructional Science, 24, 5, 321-341. 
Dolmans, D., \& Schmidt, H. (1996). The advantages of problem-based curricula. Postgraduate Medical Journal, 72, 535-538.

Dolmans, D.H.J.M., \& Schmidt, H.G. (1994). What drives the student in problem-based learning? Medical Education, 28, 372-380.

Gijselaers, W.(1988). Kwaliteit van het onderwijs. Studies naar de betrouwbaarheid, validiteit en bruikbaarheid van studentoordelen [The quality of education. Studies of the reliability, validity and usability of student surveys]. Gulpen, the Netherlands: Alberts/Druko.

Greening, T. (1998). Scaffolding for success in PBL. Medical Education Online [serial online] 3, 4. http://www.med-ed-online.org/f0000012.htm.

Guzdial, M. (1998). Technological support for project-based learning. In C. Dede (Ed.), Learning with technology (pp. 47-72). Alexandria, VA:ASCD.

Hmelo, C.E., \& Evensen, D. (2000). Introduction. In D. Evensen \& C.E. Hmelo (Eds.), Problembased learning: a research perspective on learning interactions (pp.1-16). Mahwah, NJ: Erlbaum.

Houlden, R. L., Collier, C. P., Frid, P. J., John, S. L., \& Pross, H. (2001). Problems identified by tutors in a hybrid problem-based learning curriculum. Academic Medicine, 76, $l, 81$.

Jonassen, D. (1997). Instructional design models for well-structured and ill-structured learning outcomes. Educational Technology Research and Development, 45, 1, 65-94.

Kinzie, M. B. (1990). Requirements and benefits of effective interactive instruction: Learner control, self-regulation and continuing motivation. Educational Technology Research and Development, 38 , $1,5-21$.

Krajcik, J.S., Blumenfeld, P.C., Marx, R.W., Bass, K.M., Fredericks, J., \& Soloway, E. (1998). Inquiry in project-based science classrooms: Initial attempts by middle school students. The Elementary School Journal, 94, 483-497.

Marx, R.W., Blumenfeld, P.C., Krajcik, J.S., \& Soloway, E. (1997). Enacting project-based science: Challenges for practice and policy. Elementary School Journal, 97, 341-358.

McLoughlin, C., \& Hollingworth, R. (2001). The weakest link: is web-based learning capable of supporting problem-solving and metacognition? [On-line] Available: www.ascilite.org.au/conferences/ melbourne01/pubs/ list.html

Norman, G.R., \& Schmidt, H.G. (1992). The psychological basis of problem-based learning: a review of the evidence. Academic Medicine, 67, 557-565.

Pepper, K., \& Hare, D. (1999). Development of an evaluation model to establish research-based knowledge about teacher education. Studies in Educational Evaluation, 25, 4, 353-377.

Salomon, G. (1996). Studying novel learning environments as patterns of change. In S. Vosniadiou, E. De Corte, R. Glaser \& H. Mandl (Eds), International perspectives on the psychological foundations of technology-based learning environments ( pp. 363-377). Mahwah, NL: Erlbaum. 
Salomon, G., \& Perkins, D.N. (1989). Rocky roads to transfer: Rethinking mechanisms of a neglected phenomenon. Educational Psychologist, 24 (2), 113-142.

Savery, J.R., \& Duffy, T.M. (1995). Problem Based Learning: An instructional model and its constructivist framework. Educational Technology, 35, 5, 31-38.

Scardamelia, M., Bereiter, C., MvLearn, R.S., Swallow, J., \& Woodruff, E. (1989). Computer supported intentional learning environments. Journal of Educational Computing Research, 5, 51-68.

Schanck, R., \& Cleave, J. (1995). Natural learning, natural teaching: Changing human memory. In H. Morowitz \& J. Singer (Eds.), The mind, the brain, and complex, adaptive systems (pp. 175-202). Reading, MA: Addison-Wesley.

Segers, M.S.R. (2003). Evaluating the OverAll Test: Looking for multiple validity measures. In: M. Segers, F. Dochy \& E. Cascallar (Eds.). Optimising new modes of assessment: In search of qualities and standards (pp. 119-141). Dordrecht/Boston/London: Kluwer.

Stake, R.E. (1967). The countenance of educational evaluation. Teachers College Record, 68, 7 , 523-540.

Taconis, R., Ferguson-Hessler, M.G.M., \& Broekkamp, H. (2001). Teaching science problemsolving: An overview of experimental work. Journal of Research in Science Teaching, 38, 4, 442-468.

Thomas, J.W. (2000). A review of research on project-based learning. [On-line] Available: http://www.bobpearlman.org/BestPractices/PBL.htm

Vermunt, J.D., \& Verschaffel, L. (2000). Process-oriented teaching. In R.J. Simons, J. Van der Linden \& T, Duffy (Eds.), New learning (pp. 209-225). Boston, Dordrecht: Kluwer.

Vermunt, J.D., \& Verloop, N. (1999). Congruence and friction between learning and teaching. Learning and Instruction, 9, 257-280.

Vernon, D.T., \& Blake, R.L. (1993). Does problem-based learning work? A meta-analysis of evaluative research. Academic Medicine, 68, 550-563.

Williams, S.M. (1992). Putting case-based instruction into context: Examples from legal and medical education. Journal of the Learning Sciences 2 (4), 367-427.

\section{The Authors}

MIEN SEGERS is professor of Educational Sciences at the department of Educational Sciences of the University Leiden (the Netherlands) and at the department of Educational Development and Research of the University Maastricht (the Netherlands). Her major research interests are the evaluation and optimisation of learning in student-centred learning environments (such as problem-based learning environments) and quality aspects of new modes of assessment. She has been the coordinator of the Special Interest Group Assessment and Evaluation of the European Association of Research on Learning and 
Instruction (EARLI) and is currently appointed as the coordinator of the Special Interest Group Higher Education of EARLI.

EMILY TEUNISSEN is researcher at the department of Educational Development and Research of the University of Maastricht (the Netherlands). Her research involves the areas students' learning (styles) and study progress. Further activities concern the training of tutors in a problem-based learning environment and being a tutor.

PIET VAN DEN BOSSCHE is a Ph.D. student at the department of Educational Development and Research of the University Maastricht (the Netherlands). His research focuses on knowledge sharing and development in teams. As part of this broader interest he also conducts research on student-centred learning environments such as problem-based learning.

Correspondence: <m.segers@educ.unimaas.nl> 
Appendix

\section{Example of an Open-Ended Case-Based Question}

We consider the case of a small open economy in the Economic and Monetary Union that is on the brink of overheating. In the OECD "General Assessment" of June 2001 (pp. 39-40), examples of this situation are Finland, Ireland, the Netherlands and Spain. For the analysis, we use a Mundell-Fleming model with a changing price level (see Mankiw, ch. 12-6). To simplify the analysis, we assume that the small country only trades with the rest of EMU. We can therefore neglect the rest of the world outside EMU. Also, we assume expected inflation to be zero, so that the nominal interest rate equals the real interest rate.

For the small country (say Spain), the following relations hold:

(1) $\mathrm{y}=\mathrm{C}(\mathrm{Y}-\mathrm{T})+\mathrm{I}\left(\mathrm{r}^{*}\right)+\mathrm{G}+\mathrm{NX}\left(\mathrm{EP} / \mathrm{P}^{*}\right) \mathrm{IS}^{*}$

(2) $\mathrm{M} / \mathrm{P}=\mathrm{L}\left(\mathrm{r}^{*}, \mathrm{Y}\right) \mathrm{LM}^{*}$

Here, $\mathrm{r}^{*}$ is the common real interest rate in the EMU (set by the ECB), $\mathrm{P}^{*}$ is the average price level in the EMU, and $\mathrm{E}$ is (by definition) unity since all countries in the EMU trade in the same eurocurrency. All variables without asterisk are domestic (Spanish) variables

The initial situation is given in the graph below. Also assume that during the analysis the European price level $\mathrm{P}^{*}$ remains constant.

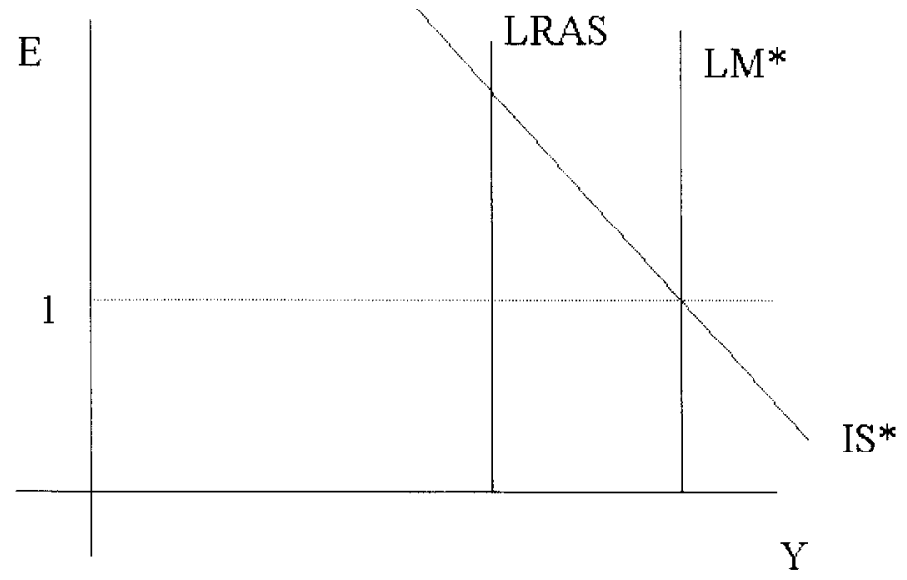


According to the OECD (p.40): "...in the absence of national monetary policy the only macroeconomic policy instrument available to contribute to stabilisation is fiscal policy."

2a. Use the graph on the answer form to show graphically how fiscal policy should be set to bring the Spanish economy back to its long-run equilibrium. Discuss where this long-run equilibrium will be in the graph and how the transition from the starting point will take place. ( 7.5 points)

However, as argued by the OECD, fiscal policy may not be available in these countries. Therefore, the OECD (p.40) concludes: "... the unwinding of excess demand is by default left to market forces ... and Spain are already experiencing much faster growth in unit labour costs in the total economy than other members of the monetary union, and this loss in competitiveness vis-a-vis their euro partners is likely to persist in the coming years. The eventual gradual weakening of the net external balance will act to reduce the extent of the overheating."

2b. Discuss precisely how the "market forces" would influence the IS* and LM* curves, to arrive at the long-run equilibrium in the end. Illustrate again graphically. 